У ДК 331.556(477)+314.131:323.26(477.5)
DOI: 10.24144/2078-1431.2019.2.(23).20-32

Іван Артьомов,

кандидат історичних наук, доцент,

директор НН Інституту євроінтеграційних досліджень ДВНЗ «Ужгородський національний університет»

\title{
СУЧАСНІ МІГРАЦІЙНО-ДЕМОГРАФІЧНІ ВИКЛИКИ ДЛЯ УКРАЇНИ ТА ШЛЯХИ ЇХ МІНІМІЗАЦІї
}

Стаття е продовженням досліджень, які автор проводить з 2005 року. Окремі наукові результати оприлюднено після підписання Угоди про реадмісію Украӥни з ЕС у 2014 роц̧і.

У статті розглянто виклики, спричинені міграційними процесами, демографічною ситуацією та проблемами з внутрішньо переміщеними особами зі Сходу Украйни. Здійснено аналіз причин та наслідків як внутрішньої, так $i$ зовнішньої міграцъї українцьів, викликаних геополітичними трансформаціями, щзо впливають на всі без винятку аспекти життя суспільства. Наголошено, щзо інтенсивність, характер, спрямованість міграцзї̈ населення України кардинально змінилися за роки незалежності, коли громадяни набули право на свободу пересування. Анексія Криму та конфлікт на Донбасі обумовили масштабні вимушені переміщення населення, поглибивщи економічну кризу та інтенсифікувавии трудову міграціюю.

Окреслено загальне бачення шляхів мінімізації існуючих викликів з урахуванням місия і ролі Украйни у сучасному геополітичному просторі.

Ключові слова: міграція, внутрішньо переміщені особи, демографічна ситуація, конфлікт на Сході Украйни, трудова міграція.

The article continues the research that the author has been conducting since 2005 year. Some scientific researches were published by the author after signing the Agreement on readmission of Ukraine with the EU.

The article highlights the challenges posed by migration processes, demographics, and problems with internally displaced persons from Eastern Ukraine. The causes and effects of both internal and external migration of Ukrainians caused by geopolitical transformations affecting all aspects of society are analyzed. It was emphasized that the intensity, nature, orientation of migration of the Ukrainian population changed a lot during the years of independence when citizens gained the right to freedom of movement. The annexation of the Crimea and the conflict in the Donbass caused large-scale forced displacement of the population, exacerbating the economic crisis and intensifying labor migration.

Particular attention was paid to the demographic situation in Ukraine: since 1993 from 52 million people the population decreased by almost 10 million. In 2010-2015, the natural reduction was an average of more than 160,000 people a year. 
Zero GDP growth recorded in 2013 changed by a decrease of 9.9\% in 2015 as a result of the conflict in Eastern Ukraine and falling commodity prices in the global market.

The author identifies factors that have both national and regional levels, analyzes the data of recent sources and publications on research issues such as: Report of the Representation of the International Organization for Migration in Ukraine for 20142016; recent works of V. Horbulin; research conducted by the "Mirror Weekly»; analytical data, conclusions and suggestions on these issues by Professor Andriy Haidutsky and many other publications.

The overall vision of ways to minimize existing challenges is outlined, taking into account the place and role of Ukraine in the modern geopolitical space.

Key words: migration, internally displaced persons, demographic situation, conflict in Eastern Ukraine, labor migration.

За останні роки, особливо після отримання безвізового режиму з $\mathrm{EC}$, проблема міграції, демографічна ситуація та війна на Сході України, що привела до тимчасового переміщення близько 2 млн чол., загострили існуючі викдики в різних сферах життедіяльності суспільства.

Для правового регулювання і мінімізації цих викликів Кабінет Міністрів України прийняв розпорядження №482 від 12 липня 2017 р. «Про схвалення Стратегії державної міграційної політики України на період до 2025 року». Але суттєвого покращення ситуації не відбулося.

Геостратегічне значення України в геополітичному просторі сучасності залишається надзвичайно привабливим як для східних сусідів, так і для ЄС та США зокрема. Відомий вислів Збігнєва Бжезинського «Україна - це шах і мат для будь-якого гравця, що оперує у Східній Європі. А хто контролюе Україну, той контролюе Євразію». Ці пророчі висновки і є основною причиною боротьби Сходу і Заходу за Україну.

Глобальним викдиком сьогодення для багатьох країн світу є міграція, біженці та демографічні проблеми. Враховуючи, що на земній кулі проживає більше 7 млрд людей, кількість яких щорічно збільшуеться на 80 млн, міграційні процеси є закономірним, об'єктивним явищем розвитку людства. Про потреби країн світу в припливі мігрантів свідчать дані, наведені на рис.1.

Зазначимо, що зовнішня трудова міграція є природною реакцією населення на негативні зміни у соціально-економічному житті суспільства в період структурних перетворень в економіці, за умови нерозвиненості та деформованості внутрішнього ринку праці, масового і галузевого регіонального безробіття. На жаль, сьогодні держава практично не реалізує довгострокову стратегію та дієві механізми, які б могди принципово змінити ситуацію на внутрішньому ринку праці, вплинути на мотивацію трудових колективів, передусім збільшити конкурентоспроможність зазначеного ринку.

Характерною особливістю цих процесів є те, що мігранти стали важливим джерелом наповнення національних бюджетів. Вони є, по суті, інвестиційними донорами для своїх країн [1]. 


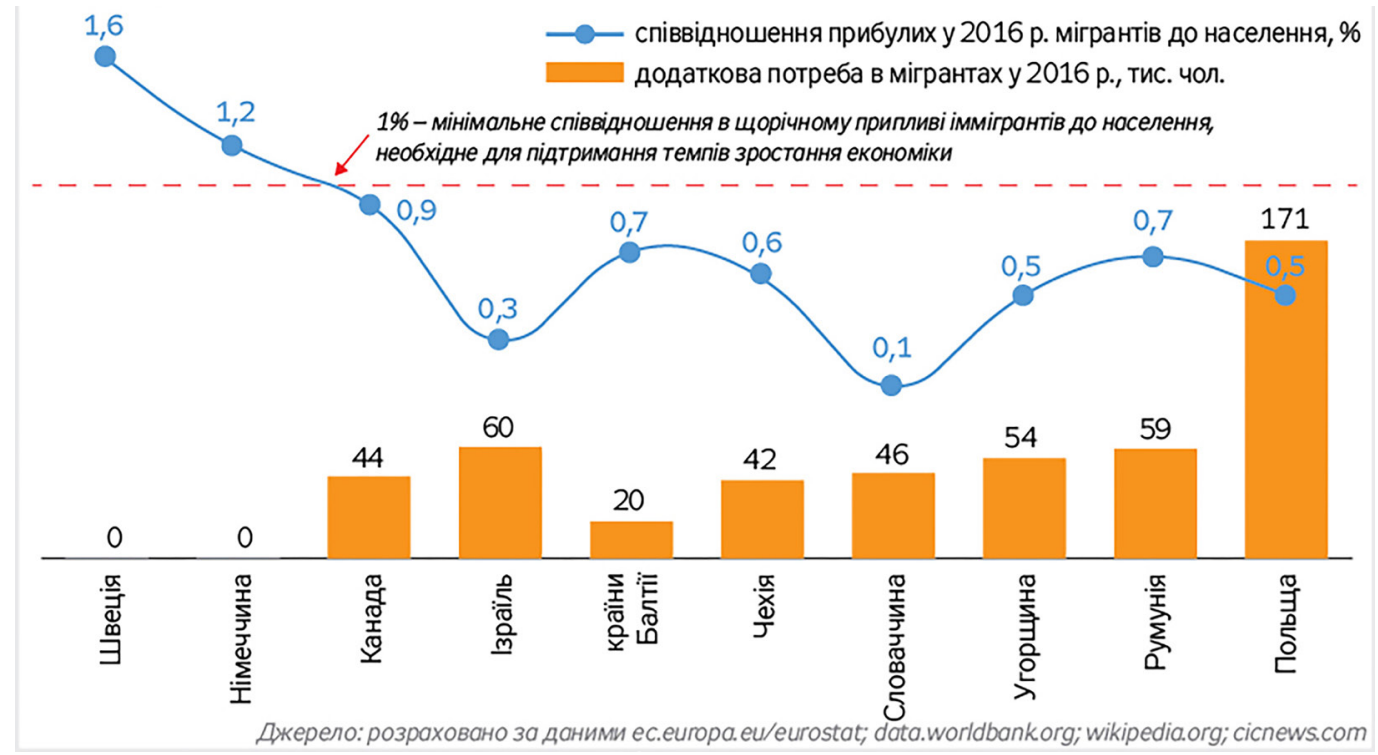

Рис. 1. Потреби країн світу у припливі мігрантів у 2016 р. [2].

Загалом мігранти стали переказувати більше грошей з Польщі, Росії, Іспанії та США. Всього у світі, включаючи країни з високим рівнем доходу, мігранти 2018 року переказали 689 млрд доларів, 2017-го - 633 млрд доларів. Основними одержувачами грошей від трудових мігрантів 2018 року стали Індія, Китай, Мексика, Філіппіни та Єгипет [3].

Тому є усі підстави говорити про те, що мігранти фактично творять ВВП своїх держав. На початку листопада 2019 року Світовий банк опублікував показники ТОП 20 держав світу, які забезпечують приріст світового ВВП. Лідерами гдобального світового економічного зростання є Китай $32 \%$, США - 13,8\%, Індія - 13.5\%, Індонезія - 3,9\%, Японія - 2,4\%, Росія - 2\%, Німеччина $-1,6 \%$, Франція - 1,5\%, Великобританія - 1,5\%, Египет - 1,5\%, Бразилія - 1,4\% та інше [4].

Так, грошові перекази до Європи і Центральної Азії збільшилися приблизно на 11\%, до 59 млрд доларів. У цьому регіоні банк називає Україну основним одержувачем грошей мігрантів: до країни 2018 року надійшло понад 14 млрд доларів, це на 19\% більше, ніж 2017 року. До слова, раніше було названо ТОП-5 країн-лідерів з грошових переказів до України [3].

Для прикладу, надходження від трудових мігрантів у процентному відношенні до ВВП країн за 2017 р. становиди: Киргизія - 41,3\%, Таджикистан - 36,8\%, Молдова - 14,8\%, Узбекистан - 12,7\%, Вірменія - 9,1\%, Україна $-8,3 \%$, Білорусь - 2\%. Показовими для порівняння є дані щодо надходжень від трудових мігрантів у перерахунку на одного жителя України. Так, показники варіюються за країнами: Киргизія - 413 дол., Вірменія - 365,5 дол., Молдова - 343 дол., Таджикистан - 292 дол., Україна - 220 дол., Узбекистан - 122,5 дол., Білорусь - 111,5 дол.[5].

Надходження від трудових мігрантів в Україну порівняно з деякими бюджетними показниками у 2017 р. такі: доходи держбюджету - 29,8 млрд дол.; податкові надходження - 16,9 млрд дол.; митні надходження - 11,4 
млрд дол.; витрати Пенсійного фонду - 10,9 млрд дол.; надходження від трудових мігрантів - 9,3 мхрд дол.; витрати на оборону Украйни - 4,9 млрд дол.; погашення кредитів МВФ у 2018 р. - 4,5 млрд дол.; уся макрофінансова допомога Украйні у 2017 р. - 3,3 млрд дол.; прямі іноземні інвестиції- 2,3 млрд дол.; дохід НБУ - 2,3 млрд дол. тощцо [5].

Авторитетне польське видання Dziennik Gazeta Prawna [3] опублікувало рейтинг 50 найвпливовіших людей економіки Подьщі. На другому місці опинилися українські мігранти. Видання зазначило, що українці $є$ «колективним героєм польської економіки». У цьому рейтингу українські мігранти випередили навіть президента Польщі Анджея Дуду (посів трете місце) та всіх успішних особистостей країни. Це свідчить про дуже важливу роль українців в економіці Польщі.

Мігранти відіграють значну роль в економіці нашої держави. На відміну від іноземних інвестицій, грошові перекази мігрантів досить рівномірно розподіляються між регіонами України. До прикладу, у 21 із 22 областей перекази мігрантів істотно перевищують приплив іноземних інвестицій, причому майже в половині регіонів - у десять разів і більше (рис. 2).

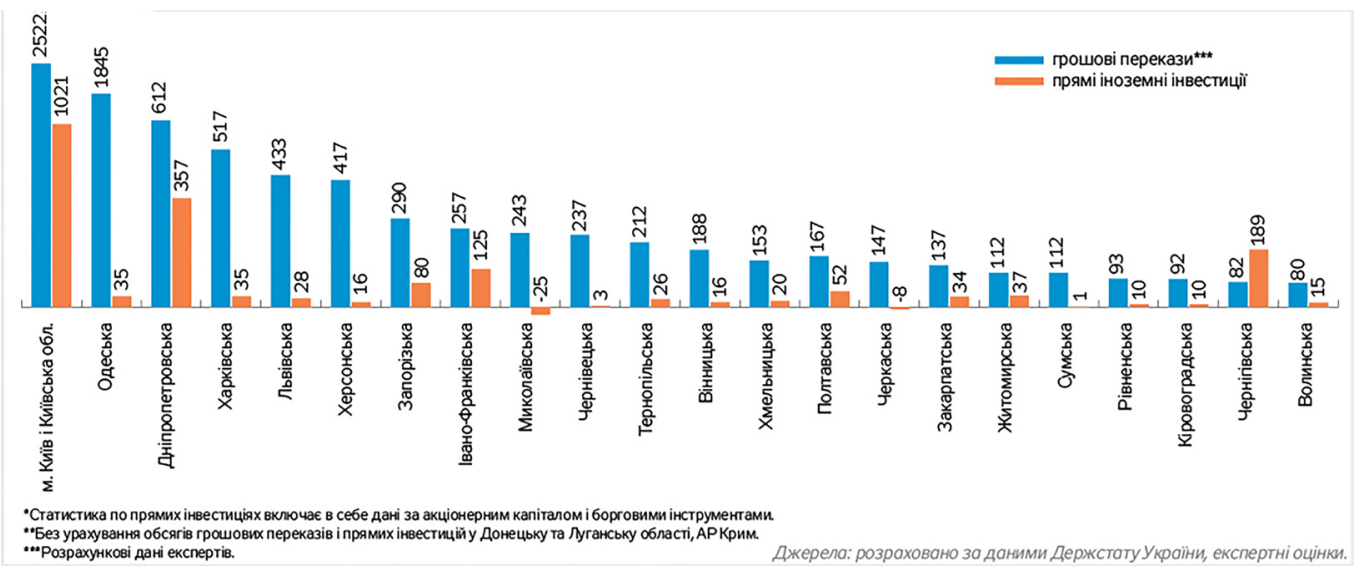

Рис. 2. Порівняння припхиву грошових переказів і прямих іноземних інвестицій̈ регіони України ${ }^{* *}$ у 2017 р., млн дол. США [3]

Ще одним підтвердженням важдивості надходжень від трудових мігрантів є дані в перерахунку на одного українця порівняно з іншими державами.

Поряд 3 позитивними факторами фінансових надходжень від трудових мігрантів слід зазначити серйозні недоліки. Це зокрема дисбаланс на трудовому ринку України, який настав у наслідок того, що близько 10 млн найбільш кваліфікованих молодих українців працюють на економіки інших країн.

За різним даними, які наводяться у виданні «Дзеркало тижня» [6], за межами України заробляють на життя від шести до восьми мільйонів наших громадян. Втім, частково вже не тільки наших, бо тенденція «виїхати, заробити й повернутися» переростає у «виїхати, влаштуватися й залишитися». Навіть офіційна статистика відображає цей тренд - кількість зареє- 
строваних безробітних за 2017 рік скоротилася з 429 тис. осіб у січні до 354 тис. у грудні, але кількість вакансій на українському ринку праці, навпаки, за цей самий період зросла 347 до 50,5 тис. (Держслужба зайнятості). 3 тих, хто ще не сів у поїзди й маршрутки, що йдуть на Захід і Схід, - майже 30\% живуть із думкою про те, що це слід зробити. 64\% заявили, що не замислювалися про те, щоб виїхати з України.

(на 1 січня)

Міські поселення та сільська місцевість
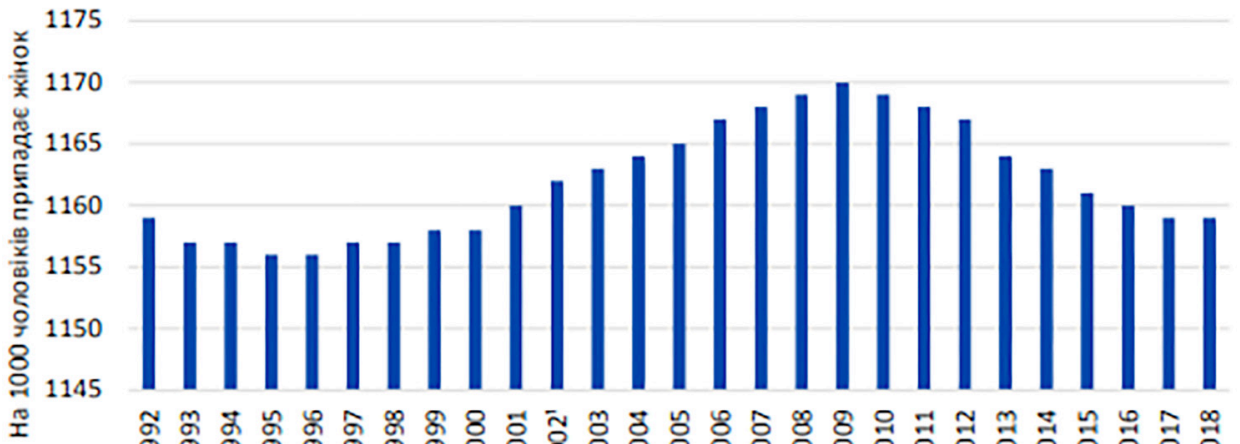

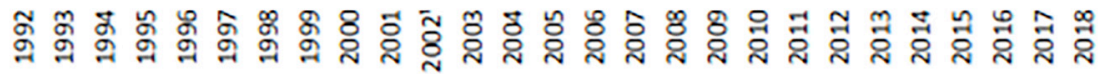

Міські поселення
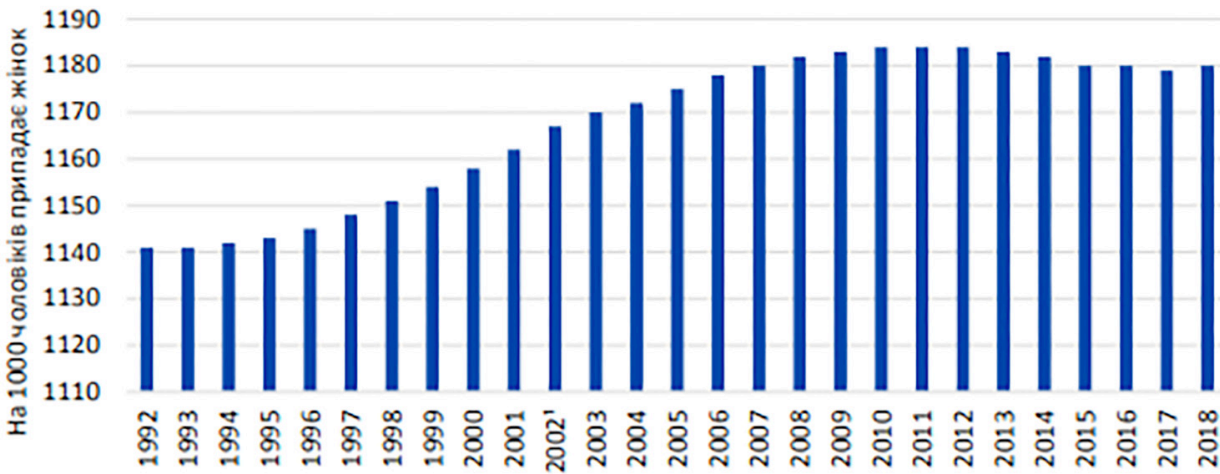

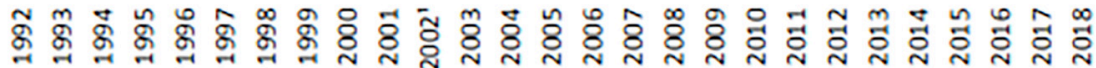

Сільська місцевість
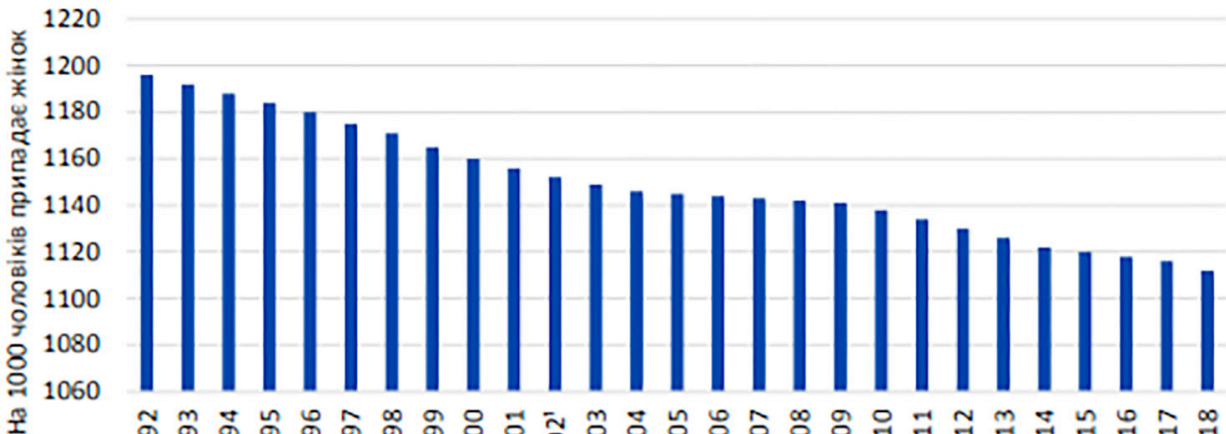

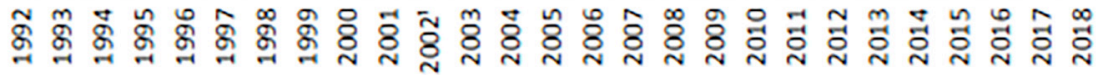

Рис. 3. Співвідношення чоловіків і жінок у 1992-2018 рр. [7] 
Препаруючи отримані цифри, ми стикаємося 3 передбачуваною, але від цього не менш тривожною картиною: 3 тих, хто має намір покинути Україну, 55\% - молодь у віці від 18 до 29 років; 44\% - від 30 до 39 років; 33\% - 40-50-річні. Країна в ії нинішньому стані не може адекватно зреагувати на цей виклик. Гостру нестачу інтелектуалів, висококласних фахівців і майстеровитих дюдей Україна відчуває вже сьогодні. 3 тих, хто готовий шукати щастя на чужині, 40\% - люди з вищою освітою; 27,6 - із середньою спеціальною; 23,2 - із середньою і 17,8\% - із неповною середньою освітою [6].

Замислюються про те, щоб виїхати з України, 32\% всього чоловічого населення країни і $27 \%$ - жіночого. Найбільш ураздивий західний регіон - 34\% його жителів планують виїхати. У центральному такі плани виношують 27\%, на півдні країни - 29\% і на сході - кожен четвертий житель [6].

Адже середня зарплата в Україні на листопад 2017-го становила 7479 грн, або 213 євро за актуальним курсом. Водій вантажівки або автобуса в Подьщі заробляе від 2800 до 4000 здотих, або 700-900 евро на місяць, і роботодавець готовий його не тільки годувати й забезпечити житдом, а й документи за нього оформити [6].

Цікавими є відповіді потенційних мігрантів на запитання «На який період ви плануєте виїхати з України?»

\begin{tabular}{|l|c|}
\hline Доти, доки в Україні не почнеться стійке економічне зростання & 26,1 \\
\hline Я хочу їздити на сезонні роботи за кордон, але не виїжджати назовсім & 15,4 \\
\hline Назавжди & 14,1 \\
\hline Я хотів би заробити гроші, а потім відкрити свою справу в Україні & 12,8 \\
\hline Я би хотів би отримати нові знання й досвід, а потім повернутися в Україну & 9,3 \\
\hline Поки не закінчиться війна & 2,9 \\
\hline Інше & 0,4 \\
\hline Важко сказати/Не знаю & 19,0 \\
\hline
\end{tabular}

Джерело [6]

Як бачимо, кожен четвертий з опитаних має намір перечекати за кордоном лихоліття, поки в Україні все, очевидно, саме по собі врегулюеться й розквітне.

При збереженні подібної тенденції сегмент ринку низькоквадіфікованої праці в Україні може бути заповнений нелегальними трудовими мігрантами з країн Азї̈, Африки, сусідньої Моддови, інших країн СНД.

Основними внутрішніми чинниками, що зумовлюють трудову міграцію українців як на загальнодержавному, так і регіональному рівнях, $є$ такі:

- високий рівень галузевого та регіонального безробіття в умовах структурних трансформацій в економіці;

- суттеве зниження рівня добробуту серед окремих соціальних груп, потреба в коштах на придбання житла, освіту дітей, відкриття власного бізнесу, які неможливо реально та легально заробити; 
- невідповідність між рівнем оплати праці та фактичною вартістю життя в Україні та суттєво нижчий рівень оплати праці, ніж у країнах мождивого працевлаштування.

Основні зовнішні чинники визначають переважно стан та особливості зовнішнього ринку праці:

- сталий попит на українських заробітчан, як легальних, так і нелегальних трудових мігрантів у приймаючих країнах;

- значно вищі рівні оплати праці, ніж в Україні, та вигідніші умови для працевлаштування. Так, середньомісячна реальна заробітна плата становила в 2014 р. 94\% від рівня 2013 р., а в 2015 р. - 80\% від рівня попереднього року. Хоча номінально середня заробітна плата зросла - 3480 грн. в 2014 р. і 4195 грн. в 2015 р., в результаті стрімкої інфляції національної валюти в доларовому еквіваленті вона різко скоротилася - 292 дол. США в 2014 р. і 192 дол. США в 2015 р.[8];

- можливість легалізації з метою подальшої зміни місця постійного проживання та інші.

Умовно структура трудової еміграції громадян України може бути представлена трьома групами, що суттєво відрізняються умовами, статусом та тривалістю працевлаштування, професійною, статево-віковою, освітньою структурами мігрантів, сферами зайнятості, географією країн, що приймають:

- офіційна (легальна) трудова міграція, за якої українські громадяни виїжджають за кордон через структури, що здійснюють ліцензовану посередницьку діяльність з працевлаштування;

- неофіційна (прихована) легалізована трудова міграція, за якої цілями виїзду за кордон декларуються туризм, відвідування родичів тощо. Проте фактично ця категорія українських заробітчан працює нелегально;

- неофіційна (прихована) нелегальна трудова міграція - категорія мігрантів, які працюють у тіньовому секторі економіки країн-реципієнтів, передусім це сфера приватних господарств, готельно-ресторанний бізнес, сільськогосподарські (сезонні) роботи та інші.

Позитивними наслідками трудової міграцїі є:

- надходження в Україну значних коштів, зароблених за кордоном;

- накопичення досвіду життя та роботи в іншому соціально-економічному середовищі в ринкових умовах, формування європейської системи цінностей;

- формування нових осередків української діаспори, розширення їх географіï.

Негативними наслідками трудової міграції є:

- погіршується вікова структура населення - зростає чисельність населення похилого віку і скорочується - молоді;

- депопуляція. В Україні більше людей помирає, ніж народжується. За даними ООН, до 2050 року українів буде трохи більше 36 мільйонів. За інформациію Держстату, кількість померлих перевищила кількість народжених у пропорціях 100 до 57 (не враховуючи 
Донецьку та Дуганську області, АР Крим). За 26 років незалежності українців стало менше на 9 мільйонів осіб. В Україні досить низька народжуваність, при цъьому тривалість життя нижча, ніж у середньому по Европі [9];

- погіршується співвідношення між працездатним і непрацездатним населенням. На 9,5 млн працюючих українців припадає 12,5 млн пенсіонерів;

\begin{tabular}{|c|c|c|c|c|c|c|c|c|c|c|c|}
\hline 44,72 & 44 & 43,1 & 42,2 & 41,1 & 40 & 38,9 & & & & & \\
\hline 2016 & 2019 & 2022 & 2025 & 2028 & 2031 & & 37,5 & 36,4 & 35,2 & 34 & 32,9 \\
\hline & & & & & & 2034 & 2037 & 2040 & 2043 & 2046 & 2050 \\
\hline
\end{tabular}

\section{Джерело: Комплексний демографічний прогноз України на період до 2050 року /Інститут демографії та соціальних досліджень НАН України}

Рис. 4. Прогноз чисельності населення України за умови незмінних показників народжуваності, тривалості життя та міграції за даними 2011 р., млн осіб [8]

- відбувається «відплив інтелекту», що є однією з найвагоміших проблем у контексті перспектив України на шляху науково-технічного прогресу. На сьогодні за кордоном працює до 35\% українських вчених. Втрати у сфері науки у 2007 році оцінювалися в сумі близько 2 млрд дол. на рік. Триває подальше старіння наукових кадрів;

- наростає нестача на вітчизняному ринку праці висококваліфікованих фахівців.

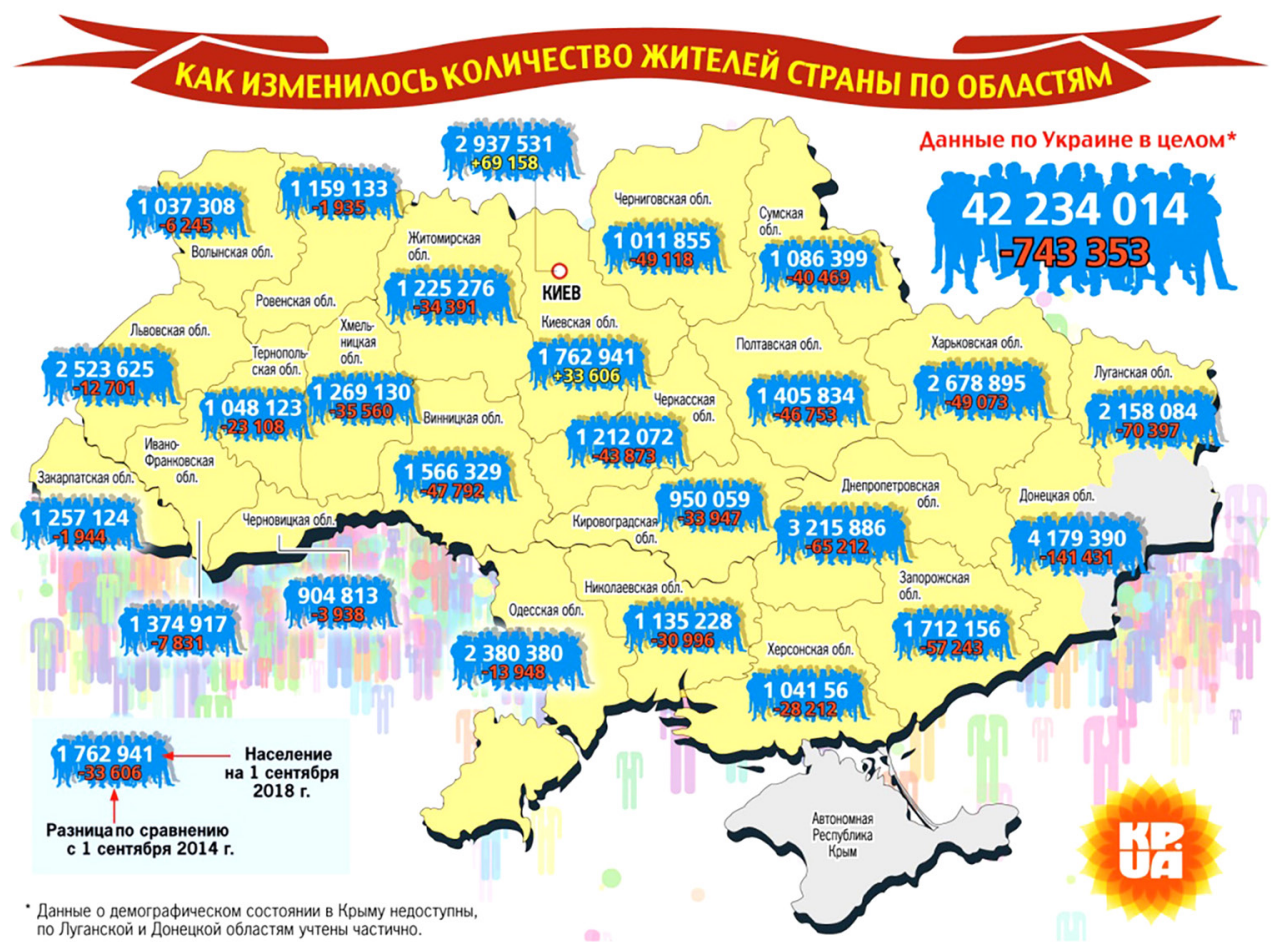

Рис. 5. Як змінилася кількість жителів України за областяли [10] 
Враховуючи вищевикладене, слід відзначити, що необхідна реформа міграційної політики держави, яка, на думку доктора економічних наук Андрія Гайдуцького, має вирішити такі завдання:

1. Залучення іноземних іммігрантів. Беручи до уваги, що в багатьох країнах ЕС українці вже лідери з імміграції, можна припустити, що щорічно 300-400 тис. українців виїжджатимуть до країн ЕС. Через демографічну кризу Україна додатково втрачає близько 200 тис. людей на рік. Таким чином, щорічна потреба України в іммігрантах уже становить 500-600 тис. людей. Тільки в цьому разі країна зможе компенсувати відплив і природні втрати людських ресурсів і спрямувати їх на розвиток економіки.

2. Повернення українських мігрантів. Досвід інших країн показує, що в основі політики повернення емігрантів лежить комплекс фінансово-економічних та організаційних механізмів (мотиваційних програм). Їх запуск дозволяе спочатку істотно збільшити приплив грошових переказів та інвестицій мігрантів, які виїхали, а вже потім вони починають самі повертатися на батьківщину. Під фінансово-економічними механізмами і програмами розуміють плідну роботу влади та фінансово-банківського сектора. Серед ключових мотиваційних продуктів можна виділити розміщення облігацій серед мігрантів і діаспори. За 60 років близько 20 країн (включаючи Індію, Ізраїль) залучили понад 50 млрд дол. розміщенням облігацій для своєї діаспори в країнах їх проживання. Ці гроші йдуть на розвиток інфраструктурних проєктів на батьківщині, фінансування держборгу, будівництва соціально важливих проєктів.

3. Запуск організаційних механізмів та програм. На першому етапі потрібно створити Міністерство у справах мігрантів і діаспори для розвитку мотиваційної політики їх реінтеграції в Україну. Уже в 46 країнах є центральний орган (у т.ч. у Вірменії, Грузіі, Ірландії, Канаді), який розробляє ключові мотиваційні механізми і працює 3 донорами. Також необхідно створити профільні підрозділи в центральних і регіональних органах влади для впровадження мотиваційної політики міністерства. Уже в 56 країнах працює понад 400 спеціальних підрозділів, які реалізують програми 3 повернення мігрантів на батьківщину. Крім цього, необхідно увести посаду аташе у справах мігрантів при посольствах України. У багатьох країнах Азіі з високим рівнем переказів при кожному посольстві є такі позиції.

4. Створення профільних підрозділів у фінансово-банківських організаціях. У 30 країнах світу в найбільших банках створено спеціальні підрозділи з розробки послуг та залучення грошей мігрантів і діаспори. Крім банків, влада може залучити міжнародних донорів та асоціації діаспор. 3 іншого боку, Україна повинна стимулювати повернення українських емігрантів, але робити це необхідно запуском мотиваційних програм для збільшення їхніх грошових переказів на батьківщину. Тут найкращий досвід мають Ірландія, Ізраїль, Філіппіни, Індія. Реалізація вище запропонованих економічних та організаційних заходів дозволить у найкоротший строк встановити контакт з українськими мігрантами, стимулювати їх повернення розвитком їхнього підприємництва на батьківщині. Крім того, впровадженням мотиваційних програм і проєктів Україна зможе регулю- 
вати і контролювати так званий відплив мізків (brain drain), перетворювати його на циркуляцію мізків (brain circulation) і максимально використовувати знання діаспори (brain gain).

5. Законодавче оформлення міграційної політики та чітке визначення іiі цілей, інструментів та імплементація прийнятих політичних рішень та законодавчих норм, зокрема реалізація цілей і завдань, визначених Стратегією державної міграційної політики України на період до 2025 р. [11] та виконання Плану заходів із іiі реалізації. Для цього доцільно посилити роль Міністерства соціальної політики України, яке має виконувати провідну роль у регулюванні трудової міграції, зокрема підрозділу міністерства, на який покладено відповідні питання. Для забезпечення координації діяльності в міграційній сфері різних міністерств та відомств, місцевої влади варто створити при Уряді постійно діючу міжвідомчу комісію з питань міграційної політики держави, до складу якої залучити як представників органів виконавчої влади, так і громадянського суспільства, зокрема мігрантських організацій, експертів [12].

Проблеми Украйни щзодо тимчасово переміщених (внутрішньо переміщцених) осіб. Поряд з викликами, зумовленими міграційними процесами, значною проблемою України є внутрішньо переміщені особи.

Починаючи з 2014 р., після анексії Криму та початку військових дій на Донбасі, значною проблемою для України стало питання облаштування переселених біженців з цих регіонів, про що свідчать дані рис. 6 [8].

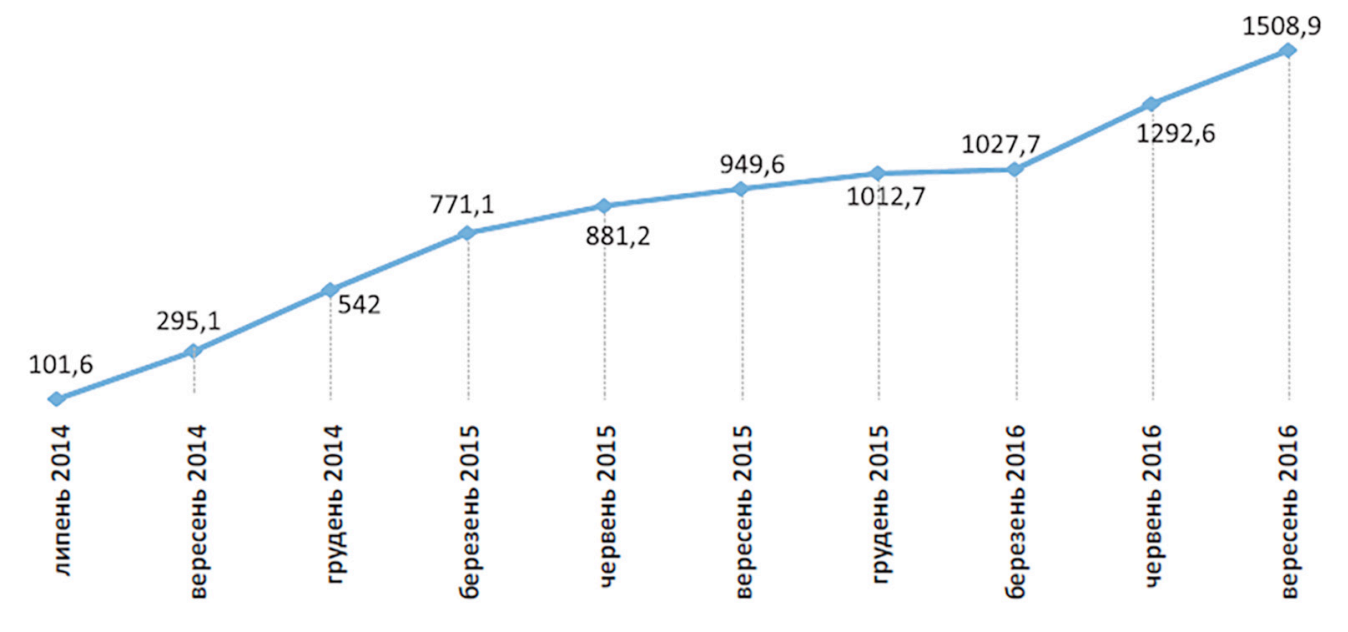

Джерело: Міжвідомчий координачійний итаб з питань соціального забезпечення громадян Украйни, які переміщуються з районів проведення антитерористичної операції та тимчасово окупованої території

Рис. 6. Оперативна інформація про переселення з Криму та непідконтрольних

Уряду України територій, Донбасу до інших регіонів, тис. осіб, 2014-2016 рр.[8]

Як зазначає В.П. Горбулін [13], перша хвиля внутрішньо переміщених осіб виникла навесні 2014 року внаслідок анексії Криму. Більшість переселенців залишила півострів з березня по серпень 2014 року. Переважно це були політично активні громадяни, журналісти, активісти релігійних гро- 
мад, студенти, які прагнули продовжити навчання в українських вишах, а також особи, професійна діяльність яких була пов'язана із застосуванням українського законодавства або здійснювалася на основі українських ліцензій (юристи, нотаріуси, фармацевти, представники малого бізнесу). Основним мотивом переселення було небажання залишатися на окупованій території. Проте з початком антитерористичної операції на території Донецької та Ауганської областей виникла нова, значно чисельніша група ВПО.

Якщо перші переселенці з Донбасу виходили переважно 3 політичних міркувань, не сприймаючи порядків самопроголошених республік, розгортання воєнних дій змусило тисячі людей рятувати своє життя. Згідно 3 першими даними 3 Донбасу, оприлюдненими в червні 2014 року, ВПО нараховувалося на той час трохи більше ніж 3 тис. осіб. Проте кожне загострення ситуації викликало нові масштабні переселення. Найінтенсивнішими вони були в липні-серпні та в жовтні 2014 року, а також січні-лютому 2015 року. Виїзди з району бойових дій відбувалися здебільшого спонтанно, з мінімальною кількістю особистих речей та коштів, часто 3 ризиком для життя.

За урядовою інформацією, станом на 23 жовтня 2015 року з тимчасово окупованої території та районів проведення АТО до інших регіонів України переміщено 973120 осіб, зокрема 3 Донецької, Дуганської областей 951891 особу, з АР Крим і м. Севастополя 21229 осіб, поміж яких 162717 дітей та 476882 інвалідів та осіб похилого віку [13].

Дослідник цієї проблематики професор О.Г. Аавер наводить дані уряду України щодо динаміки чисельності українських ВПО з Донбасу, Криму та Севастополя [14]:

Таблиця 1

Динаміка чисельності внутрішньо переміщених осіб в Україні

\begin{tabular}{|l|c|c|c|c|c|c|}
\hline & $\begin{array}{c}\mathbf{2 7 . 0 6 .} \\
\mathbf{2 0 1 4}\end{array}$ & $\begin{array}{c}\mathbf{2 9 . 0 9 .} \\
\mathbf{2 0 1 4}\end{array}$ & $\begin{array}{c}\mathbf{1 0 . 1 1 .} \\
\mathbf{2 0 1 4}\end{array}$ & $\begin{array}{c}\mathbf{2 7 . 1 2 .} \\
\mathbf{2 0 1 4}\end{array}$ & $\begin{array}{c}\mathbf{1 8 . 0 4 .} \\
\mathbf{2 0 1 5}\end{array}$ & $\begin{array}{c}\mathbf{2 8 . 0 6 .} \\
\mathbf{2 0 1 5}\end{array}$ \\
\hline Загальна чисельність & 54.400 & 339.950 & 455.175 & 614.467 & 829.373 & 868.896 \\
\hline $\begin{array}{l}\text { У тому числі з Криму та } \\
\text { Севастополя }\end{array}$ & 12.000 & 18.155 & 19.221 & 19.894 & 20.501 & 20.684 \\
\hline У \% & 22,06 & 5,34 & 4,22 & 3,24 & 2,47 & 2,38 \\
\hline
\end{tabular}

Значна активізація розв'язання проблем ВПО має базуватися на ефективній співпраці держави з бізнесом та іншими зацікавленими сторонами, зокрема волонтерськими та благодійними організаціями, міжнародними донорами. Особливу увагу варто приділяти організаціям самих ВПО, які стали впливовими членами громадянського суспідьства, змогли налагодити активну взаємодію з владою.

Необхідними є консультування з ними перед ухваленням будь-яких рішень стосовно переселенців. Водночас держава повинна координувати їхні зусилля, які могли би бути набагато результативнішими, якби центра- 
дізовано спрямовувалися на досягнення визначених стратегічних цілей, зазначалося в Посланні Президента України до Верховної Ради України у 2018 p. [12].

\section{СПИСОК ВИКОРИСТАНИХ ДЖЕРЕ}

1. Боротьба за мігрантів. Україні приготуватися. URL: https://dt.ua/internal/borotbaza-migrantiv-ukrayini-prigotuvatisya-289703_.html

2. Трудові мігранти $з$ усього світу переказали рекордний обсяг грошей. URL: https://ukr.segodnya.ua/economics/enews/trudovye-migranty-po-vsemu-mirupereveli-rekordnyy-obem-deneg-1250238.html

3. Герої нашої економіки. URL: https:/dt.ua/internal/geroyi-nashoyiekonomiki-304373_.html

4. Кузнецы глобального ВВП в 2019-м и 2024 годах: ТОП-20 государств. URL: https:// www.2000.ua/v-nomere/forum/puls/kuznecy-globalnogo-vvp-v-2019-i-2024---top20-gosudarstv.htm

5. Гастарбайтери переказують в Україну майже 10 млрд дол. на рік. Ми вже обігнали Узбекистан? URL: https://ua.112.ua/statji/hastarbaitery-perekazuiut-v-ukrainumaizhe-10-mlrd-dol-za-rik-my-vzhe-obihnaly-uzbekystan-456356.html

6. Мостова Ю., Рахманін С. Кровотеча. Чому українці покидають свою країну. URL: https://dt.ua/internal/krovotecha-chomu-ukrayinci-pokidayut-svoyu-krayinu-267394_html

7. Населення України за 2017 рік. Демографічний щорічник. Державна служба статистики України. URL: http://database.ukrcensus.gov.ua/PXWEB2007/ukr/publ_ new1/2018/zb_dy_2017.pdf

8. Міграція в Україні: факти і цифри (2016). http://iom.org.ua/sites/default/files/ff_ ukr_21_10_press.pdf

9. Україна вимирає: державі загрожує масштабна криза. URL: https://www. obozrevatel.com/ukr/society/ukraina-vimirae-derzhavi-zagrozhue-masshtabnakriza.htm

10. Как изменилось количество жителей Украины по областям. URL: https://kp.ua/ life/621862-kak-yzmenylos-kolychestvo-zhytelei-ukrayny-po-oblastiam

11. Про схвалення Стратегії державної міграційної політики України на період до 2025 року: Розпорядження Кабінету Міністрів України від 12 липня 2017 р. № 482-p. URL:http://zakon0.rada.gov.ua/laws/show/482-2017-\%D1\%80

12. Аналітична доповідь до щорічного Послання Президента України до Верховної Ради України «Про внутрішне та зовнішне становище України в 2018 році». К.: HICД, 2018.

13. Донбас і Крим: ціна повернення : монографія / за заг. ред. В. П. Горбуліна, О. С. Власюка, Е. М. Лібанової, О. М. Аяшенко. - К. : НІСД, 2015. - 474 с.

14. Лавер О.Г. Війни та народонаселення країн світу у XX-XXI стодіттях (19002016 рр.) : монографія / вид. 2-е, допов. Ужгород: РІК-У, 2018. - 760 с. - С.614.

\section{REFERENCES}

1. Borot'ba za mihrantiv. Ukrayini pryhotuvatysya [Fighting for migrants. Ukraine to prepare]. dt.ua. Retrieved from https://dt.ua/internal/borotba-za-migrantiv-ukrayiniprigotuvatisya-289703_html [in Ukrainian].

2. Trudovi mihranty z us'oho svitu perekazaly rekordnyy obsyah hroshey [Migrant workers from around the world have delivered a record amount of money].ukr.segodnya. 
ua. Retrieved from https://ukr.segodnya.ua/economics/enews/trudovye-migranty-povsemu-miru-pereveli-rekordnyy-obem-deneg-1250238.html [in Ukrainian].

3. Heroyi nashoyi ekonomiky [Heroes of our economy]. dt.ua. Retrieved from https:// dt.ua/internal/geroyi-nashoyi-ekonomiki-304373_.html [in Ukrainian].

4. Kuznetsy global'nogo VVP v 2019-m i 2024 godakh: TOP-20 gosudarstv [Blacksmiths of global GDP in 2019 and 2024: TOP-20 countries]. www.2000.ua. Retrieved from https://www.2000.ua/v-nomere/forum/puls/kuznecy-globalnogo-vvp-v-2019-i-2024--top-20-gosudarstv.htm [in Russian].

5. Hastarbaytery perekazuyut' v Ukrayinu mayzhe $10 \mathrm{mlrd}$ dol. na rik. My vzhe obihnaly Uzbekystan? [Guest workers transfer almost \$ 10 billion to Ukraine for a year. Have we already overtaken Uzbekistan?]. ua.112.ua. Retrieved from https://ua.112.ua/statji/ hastarbaitery-perekazuiut-v-ukrainu-maizhe-10-mlrd-dol-za-rik-my-vzhe-obihnalyuzbekystan-456356.html [in Ukrainian].

6. Mostova, YU., \& Rakhmanin, S. Krovotecha. Chomu ukrayintsi pokydayut' svoyu krayinu [Why Ukrainians are leaving their country]. Retrieved from https://ua.112. ua/statji/hastarbaitery-perekazuiut-v-ukrainu-maizhe-10-mlrd-dol-za-rik-my-vzheobihnaly-uzbekystan-456356.html [in Ukrainian].

7. Derzhavna sluzhba statystyky Ukrayiny. Naselennya Ukrayiny za 2017 rik. Demohrafichnyy shchorichnyk. [Ukraine's population for 2017. Demographic Yearbook. State Statistics Service of Ukraine]. Retrieved from

http://database.ukrcensus.gov.ua/PXWEB2007/ukr/publ_new1/2018/zb_dy_2017.pdf [in Ukrainian].

8. Mihratsiya v Ukrayini: fakty i tsyfry (2016) [Migration in Ukraine: Facts and Figures (2016)]. iom.org.ua. Retrieved from http://iom.org.ua/sites/default/files/ff_ukr_21_10_ press.pdf

9. Ukrayina vymyraye: derzhavi zahrozhuye masshtabna kryza [Ukraine is dying out: a large-scale crisis threatens the country]. www.obozrevatel.com. Retrieved from https://www.obozrevatel.com/ukr/society/ukraina-vimirae-derzhavi-zagrozhuemasshtabna-kriza.htm [in Ukrainian].

10. Kak izmenilos' kolichestvo zhiteley Ukrainy po oblastyam [How the number of residents of Ukraine in the regions has changed]. kp.ua. Retrieved from https:// kp.ua/life/621862-kak-yzmenylos-kolychestvo-zhytelei-ukrayny-po-oblastiam [in Ukrainian].

11. Pro skhvalennya Stratehiyi derzhavnoyi mihratsiynoyi polityky Ukrayiny na period do 2025 roku: Rozporyadzhennya Kabinetu Ministriv Ukrayiny vid 12 lypnya 2017 r. № 482-r. [On Approval of the Strategy of the State Migration Policy of Ukraine for the Period up to 2025: Order of the Cabinet of Ministers of Ukraine of July 12, 2017 No. 482-p.] [in Ukrainian].

12. Analitychna dopovid' do shchorichnoho Poslannya Prezydenta Ukrayiny do Verkhovnoyi Rady Ukrayiny "Pro vnutrishnye ta zovnishnye stanovyshche Ukrayiny v 2018 rotsi» [Analytical Report to the Annual Message of the President of Ukraine to the Verkhovna Rada of Ukraine "On Internal and External Situation of Ukraine in 2018"]. (2018). Kyiv: NISD [in Ukrainian].

13. Horbulin, V.P. (2015). Donbas i Krym: tsina povernennya [Donbass and Crimea: return price]. O.S. Vlasyuk, E.M. Libanova, O.M. Lyashenko (Eds.). Kyiv: NISD [in Ukrainian].

14. Laver, O.H. (2018). Viyny ta narodonaselennya krayin svitu u XX-XXI stolittyakh (19002016 rr.) [Wars and Populations of the World in the XX-XXI Centuries (1900-2016)]. Uzhhorod: RIK-U [in Ukrainian]. 